\title{
Use of a Glucose Controlled Insulin Infusion System (Artificial Beta Cell) to Control Diabetes during Surgery
}

\author{
S. S. Schwartz, D. L. Horwitz, B. Zehfus, B. Langer, A. R. Moossa, G. Ribeiro, E. Kaplan, \\ and A. H. Rubenstein \\ Departments of Medicine, Surgery and Anaesthesiology, The University of Chicago, Pritzker School of Medicine, Chicago, Illinois, USA
}

\begin{abstract}
Summary. An artificial beta cell has been used to achieve and maintain a preset plasma glucose concentration in five diabetic patients undergoing surgery. These subjects were compared to control groups of normal subjects receiving either saline or glucose, and diabetics receiving glucose intraoperatively. Hyperglycaemia during surgery was seen in normals (mean plasma glucose \pm SEM: $185 \pm$ $16 \mathrm{mg} / \mathrm{dl})$ and, to a greater degree, diabetics (247 \pm $36 \mathrm{mg} / \mathrm{dl}$ ) receiving glucose. Insulin and C-peptide levels did not increase during 2 hours of operation in any of the control groups, suggesting beta cell suppression during surgery. As C-peptide levels declined similarly in normal subjects whether they received saline or glucose, the hyperglycaemia seems to be due to an inability to use exogenous glucose. This is confirmed by a correlation of maximal plasma glucose to glucose infusion rate $(r=0.78, p<0.01)$. The artificial beta cell was able to achieve the same plasma glucose after 2 hours of operation (128 \pm $21 \mathrm{mg} / \mathrm{dl})$ as normal subjects receiving saline $(110 \pm$ $7 \mathrm{mg} / \mathrm{dl}$ ). The artificial beta cell proved to be a safe, convenient and effective way of monitoring and controlling the hyperglycaemia seen in diabetic patients undergoing surgery.
\end{abstract}

Key words: Artificial beta cell, diabetes, surgery, hyperglycaemia, insulin levels, C-peptide levels, $\beta$ cell reserve, insulin resistance, cortisol.

Many different methods of managing diabetics during surgery have been advocated. Each aims to avoid hypoglycaemia or hyperglycaemia and ketosis, and their potentially serious sequelae. These methods include avoiding both intravenous glucose and insulin during surgery [1], using intravenous glucose but no insulin during surgery [2], using intravenous glucose with one third to one half of the patient's usual dose of NPH or Lente insulin given subcutaneously before surgery $[3,4,5]$, intravenous glucose with the usual dose of subcutaneous NPH or Lente insulin [6], and intravenous glucose mixed with regular insulin given continuously during surgery [7-10]. The adequacy of these methods has been inferred from the low mortality of operations on diabetics $[5,6]$ and by studies suggesting reasonable plasma glucose concentrations during surgery with both subcutaneous insulin before surgery and with continuous insulin infusion during surgery [10]. However Galloway and Shuman [11] warn of the possibility of undetected hypoglycaemia under general anaesthesia and it is generally known that occasionally, although rarely, a diabetic is found to be ketotic or even in ketoacidosis after surgery. Little if any emphasis is ever given to the intraoperative monitoring of these patients' blood glucose levels.

In this regard, we have tested the principle of continuous glucose monitoring with automatic feedback control of plasma glucose by an artificial beta cell (Biostator ${ }^{\circledR}$ glucose controlled insulin-infusion system [GCIIS], Miles Laboratories, Inc.). The principle of using an artificial beta cell in surgery has been described by Pfeiffer [12], who reports using it on 12 diabetics during surgery [13]. Clarke [14] described the use of an artificial beta cell in one patient undergoing dental surgery. These previous studies have not compared the use of the GCIIS to control groups of normal and diabetic patients receiving either saline or glucose as their main intraoperative intravenous fluid. 


\section{Materials and Methods}

\section{Glucose-Controlled Insulin-Infusion System}

A constant amount $(2 \mathrm{ml} / \mathrm{h})$ of the patient's blood is withdrawn from an arm vein and passed through a glucose sensor which utilizes membrane-bound glucose oxidase. A double-lumen catheter allows dilution and anticoagulation of the blood as it leaves the patient. The plasma glucose level is continuously displayed and each minute's average is printed. A preprogrammed computer using the absolute level and rate of change of plasma glucose calculates the appropriate rates of insulin and/or glucose infusion and activates their precise delivery by peristaltic pumps in the instrument. The system has been described in detail elsewhere [12, 14]. The computer program was set to maintain the plasma glucose at $100 \mathrm{mg} / \mathrm{dl}$. Periodic recalibration during the procedure, based on rapidly available Beckman Glucose Analyzer ${ }^{(B)}$ results, was done to ensure accurate glucose values.

Prior to surgery the GCIIS was brought into the operating room and calibrated, and a Beckman Glucose Analyzer and Microfuge $^{\circledR}$ (Beckman) were placed in an adjoining room. The appropriate intraoperative fluids (as determined by the protocol) were started just before or during the induction of anaesthesia. Many patients, however, had an intravenous glucose $(50 \mathrm{~g} / 1)$ solution given overnight and all patients had intravenous glucose for a short period prior to induction of anaesthesia. Procedures began between 0745 and $0800 \mathrm{~h}$, and all patients had received nothing by mouth for at least $12 \mathrm{~h}$. After induction and intubation and while the surgeons were preparing and draping the patient, an arterial catheter (used to obtain blood samples for glucose and hormone analysis) and the special venous withdrawal and diluting catheter of the instrument were inserted. An arterial catheter was used for blood sampling because one is routinely inserted by our anaesthesiologists for blood gas measurement during major operative procedures, and its use eliminated the need for another venepuncture. In those patients whose plasma glucose was to be controlled by GCIIS, the insulin/glucose infusion catheter from the instrument was inserted into the peripheral or central venous catheter used by the anaesthesiologist. If disruption of blood flow to the instrument occurred, attempts were made at flushing or changing the position of the catheter or placing a new one. If this was not possible, use of the GCIIS was discontinued and the patient's further intraoperative diabetic management was accomplished by traditional means. In the control groups, plasma glucose was monitored by the GCIIS, but the insulin-infusion part of the system was not used. Informed consent was obtained from all patients on the day before the operation, and the studies were approved by The University of Chicago Clinical Investigation Committee.

\section{Laboratory Methods and Calculations}

Hourly blood samples obtained during surgery were measured for glucose, immunoreactive insulin [15] and C-peptide [16] or free and total insulin and C-peptide [17], glucagon [18], growth hormone [19] cortisol [20] and prolactin [21]. Direct measurement of insulin and C-peptide was done on sera from normal subjects, and free and total insulin and C-peptide determined on sera from diabetic subjects. Plasma glucose values were measured independently both by the Beckman Glucose Analyzer ${ }^{(3)}$ and by a hexokinase method [22]. The former were used to calibrate the GCIIS during surgery, and the latter values were used in analyzing glucose control in the various patient groups. Thus, glucose values presented in this paper were obtained by the hexokinase method except where noted. The zero time samples were taken at the time of the first skin incision. Because patients were regarded as being "under stress" from the time of awakening on the day of surgery, no true basal samples were obtained. Glucose and all hormonal results within and between the study groups were compared by Student's t-test. Only the first two hours of operation were included in analysis of variance, as comparable data for all subjects was available for this time period. Values are stated as mean \pm SEM unless otherwise indicated.

\section{Patients and Study Groups}

Patients were selected by a physician or surgeon 24 hours prior to surgery. Patients defined as "normal" had no past history of diabetes and had normal fasting and postprandial plasma glucose values in the hospital. Diabetics were all being treated with insulin. Normal patients were randomly assigned to receive saline, $0.154 \mathrm{~mol} / 1$ (NS group), or glucose, $50 \mathrm{~g} / 1$ in $0.154 \mathrm{M}$ saline (NG group), as their main intraoperative fluid. Diabetic patients were randomly chosen to receive glucose, $50 \mathrm{~g} / \mathrm{l}$ in $0.154 \mathrm{M}$ saline (DG group) and no insulin, or to be controlled by the GCIIS (DC group) and receive $0.154 \mathrm{M}$ saline. Characteristics of the patients and their operations are shown in Table 1. There was a female preponderance in all groups except the diabetics controlled by the GCIIS. There were a similar number of obese patients in all groups. A variety of diseases and surgical procedures were represented in this study. However, similar numbers of intra-abdominal procedures were performed in each group. No patients were taking any drugs likely to affect carbohydrate metabolism (subjects NG-3 and NG-4 had been on prednisone, but this was discontinued 15 and 5 months, respectively, prior to surgery), and no patients had significant impairment of hepatic or renal function. No endocrine disorders other than diabetes were present except in subjects NG-1 (parathyroid adenoma) and NS-4 (euthyroid thyroid adenoma); subject DG-1 had been treated for Graves' disease and was euthyroid.

Patients received meperidine and/or diazepam and atropine sulfate before being brought to the operating room. Induction of anaesthesia was accomplished with thiopental followed by a relaxant (succinylcholine or pancuronium) to facilitate tracheal intubation. Anaesthesia was maintained for most patients with nitrous oxide-oxygen by controlled mechanical ventilation, and intermittent intravenous narcotic (meperidine, fentanyl, morphine sulphate or Innovar ${ }^{(3)}$ ) and relaxant (curare or pancuronium), Exceptions to this sequence were two patients who received enflurane (NS-4, NG-3) and one each who received halothane (NS-1) and ketamine (DG-2).

Plasma glucose management in diabetics was done in the following manner: patients received no insulin prior to surgery (with the exception of subject DG-5, who received 10 units of regular insulin subcutaneously 2 hours prior to surgery) and received $50 \mathrm{~g} /$ I glucose (DG group) or 0.154 saline (DC group) solutions at a rate deemed necessary by the anaesthesiologist for volume and/or blood pressure control, or for infusion of anaesthetic agents.

\section{Results}

\section{Use of the GCIIS to Monitor Patients during Surgery}

The GCIIS proved to be of no hindrance to the anaesthesiologist or surgeons. Its size, that of a large typewriter on a movable cart, permitted it to be placed behind all drapes. As shown in Table 1, procedures lasted from 2 to $10 \mathrm{~h}$ and maintenance of monitoring or control by the GCIIS was possible for 
Table 1. Patients and study groups

\begin{tabular}{|c|c|c|c|c|c|c|c|c|}
\hline Group & Subject & Age & Sex & $\begin{array}{l}\text { Obesity } \\
(\%)\end{array}$ & $\begin{array}{l}\text { Diabetes } \\
\text { Duration } \\
\text { (years) }\end{array}$ & Therapy ${ }^{\mathrm{b}}$ & $\begin{array}{l}\text { Operative procedure } \\
\text { Type }\end{array}$ & $\begin{array}{l}\text { Length }^{c} \\
\text { (h) }\end{array}$ \\
\hline \multicolumn{9}{|c|}{ Normal-saline } \\
\hline & NS-1 & 61 & $\mathrm{~F}$ & 140 & - & - & Colectomy (A-V)fistula & 4 \\
\hline & NS-2 & 46 & $F$ & 102 & - & - & Cholecystectomy & 3.25 \\
\hline & NS-3 & 52 & M & 105 & - & - & Aorto-femoral bypass & $6.25^{\mathrm{e}}$ \\
\hline & NS-4 & 28 & $\mathrm{~F}$ & 110 & - & - & $\begin{array}{l}\text { Hemithyroidectomy } \\
\text { (adenoma) }\end{array}$ & 2.75 \\
\hline & NS-5 & 26 & F & 90 & - & - & $\begin{array}{l}\text { Ileal resection }+ \\
\text { ileostomy for Crohn's } \\
\text { disease }\end{array}$ & 3 \\
\hline \multicolumn{9}{|c|}{ Normal-glucose } \\
\hline & NG-1 & 73 & $\mathrm{~F}$ & 134 & - & - & $\begin{array}{l}\text { Parathyroidectomy } \\
\text { (adenoma) }\end{array}$ & 3 \\
\hline & $\mathrm{NG}-2$ & 76 & $\mathrm{~F}$ & 94 & - & - & $\begin{array}{l}\text { Exploratory laparotomy- } \\
\text { metastatic colon carcinoma }\end{array}$ & 3.5 \\
\hline & NG-3 & 28 & M & 101 & - & - & $\begin{array}{l}\text { Proctectomy (ulcerative } \\
\text { colitis) }\end{array}$ & 5.25 \\
\hline & $\mathrm{NG}-4$ & 49 & M & 97 & - & - & $\begin{array}{l}\text { Proctectomy (ulcerative } \\
\text { colitis) }\end{array}$ & 3.5 \\
\hline & NG-5 & 62 & $\mathrm{~F}$ & 127 & - & - & $\begin{array}{l}\text { Exploratory laparotomy- } \\
\text { metastic colon carcinoma }\end{array}$ & 4.25 \\
\hline \multicolumn{9}{|c|}{ Diabetic-glucose } \\
\hline & DG-1 & 40 & $\mathrm{~F}$ & 98 & 5 & $D+I-10$ & Right radical mastectomy & 6 \\
\hline & DG-2 & 64 & M & 87 & 10 & $\mathrm{D}+\mathrm{I}-18$ & Aorto-femoral bypass & 9.5 \\
\hline & DG-3 & 61 & $\mathrm{~F}$ & 143 & 15 & $D+I-60$ & $\begin{array}{l}\text { Right hemicolectomy- } \\
\text { colon carcinoma }\end{array}$ & $5^{\mathrm{e}}$ \\
\hline & DG-4 & 71 & F & 110 & 22 & $\mathrm{D}+\mathrm{I}-55$ & $\begin{array}{l}\text { Right hemicolectomy- } \\
\text { colon carcinoma }\end{array}$ & 3 \\
\hline & DG-5 & 76 & M & 106 & 10 & $\mathrm{D}+\mathrm{I}-12$ & Revision Bilroth II & 5.5 \\
\hline \multicolumn{9}{|c|}{ Diabetic-feedback control } \\
\hline & $\mathrm{DC}-1$ & 51 & M & 98 & 38 & $D+I-45$ & Aorto-femoral bypass & 4 \\
\hline & $\mathrm{DC}-2$ & 45 & M & 100 & 5 & $D+I-35$ & Gastrectomy-ulcer & 4.5 \\
\hline & DC-3 & 27 & M & 108 & 4 & $D+I-35$ & Choledocholenterostomy & $10^{\mathrm{e}}$ \\
\hline & DC-4 & 61 & $\mathrm{~F}$ & 114 & New $^{\mathrm{d}}$ & $\mathrm{D}+\mathrm{I}-32$ & $\begin{array}{l}\text { Right total knee } \\
\text { replacement }\end{array}$ & 4 \\
\hline & $\mathrm{DC}-5$ & 58 & M & 130 & 12 & $D+I-40$ & $\begin{array}{l}\text { Exploratory laparotomy- } \\
\text { gall bladder carcinoma }\end{array}$ & 2 \\
\hline
\end{tabular}

\footnotetext{
a Percentage of ideal body weight, based on Metropolitan Life Insurance Co. Tables

${ }^{\mathrm{b}} \mathrm{D}=$ diet, $\mathrm{I}=$ insulin therapy, total daily dose in units

c From anaesthesia induction to skin closure

d Newly diagnosed

e Study terminated before end of procedure because blood flow to GCIIS could not be maintained
}

total time in all but 3 patients. Although disruption of blood flow to the instrument was occasionally a problem, it was easily recognized before it could lead to either hypo-or hyperglycaemia.

GCIIS glucose values were within $14 \%$ of independent laboratory-determined plasma glucose values. The GCIIS values, it should be noted, were venous blood values, whereas the laboratory values were obtained on arterial blood samples. Two of the DG patients (DG-3 and DG-4) required intraoperative insulin therapy (Table 2) based on our monitoring of their plasma glucose (DG-3 when it was $350 \mathrm{mg} / \mathrm{dl}$ and rising, DG-4 when plasma glucose quickly rose from 300 to $550 \mathrm{mg} / \mathrm{dl}$ after glucose solution, $50 \mathrm{~g} / \mathrm{l}$, was rapidly given to expand the patient's blood volume).

\section{Use of GCIIS to Control Plasma Glucose of Diabetics during Surgery}

Figure 1 illustrates the typical course when the GCIIS was used to control the plasma glucose concentration. The patient represented was usually treated with diet and 25 units of NPH insulin every morning. The operation, a gastrectomy, was indicated for a chronic non-healing gastric ulcer locally 
Table 2. Glucose and insulin infusion during surgery ${ }^{\mathrm{a}}$

\begin{tabular}{|c|c|c|c|c|}
\hline Group & & Duration of procedure $(\mathrm{h})$ & Glucose $(\mathrm{g})$ & Insulin (units) \\
\hline \multicolumn{5}{|c|}{ Diabetic-feedback control } \\
\hline & DC-1 & 4 & 0 & 44.2 \\
\hline & DC-2 & 4.5 & 21.5 & 30.4 \\
\hline & $\mathrm{DC}-3$ & 10 & 53.1 & 16.0 \\
\hline & DC-4 & 4 & 0 & 36.8 \\
\hline & DC-5 & 2 & 13.6 & 6.8 \\
\hline \multicolumn{5}{|c|}{ Normal-glucose } \\
\hline & NG-1 & 3 & 22.5 & 0 \\
\hline & $\mathrm{NG}-2$ & 3.5 & 100 & 0 \\
\hline & $N G-3$ & 5.25 & 150 & 0 \\
\hline & $\mathrm{NG}-4$ & 3.5 & 95 & 0 \\
\hline & NG-5 & 4.25 & 80 & 0 \\
\hline \multicolumn{5}{|c|}{ Diabetic-glucose } \\
\hline & DG-1 & 6 & 100 & 0 \\
\hline & DG-2 & 9.5 & 190 & 0 \\
\hline & DG-3 & 5 & 175 & $10 \mathrm{u}$ reg. at $2 \mathrm{~h}$ \\
\hline & $\mathrm{DG}-4$ & 3 & 75 & $10 \mathrm{u} \mathrm{reg}$. at $1 \mathrm{~h}+2.5 \mathrm{~h}$ \\
\hline & DG-5 & 5.5 & 100 & $10 \mathrm{u}$ NPH subcutaneous \\
\hline & & & & $2 \mathrm{~h}$ before surgery \\
\hline
\end{tabular}

a Amounts of glucose and insulin are those given during the entire duration of procedure as listed for each subject
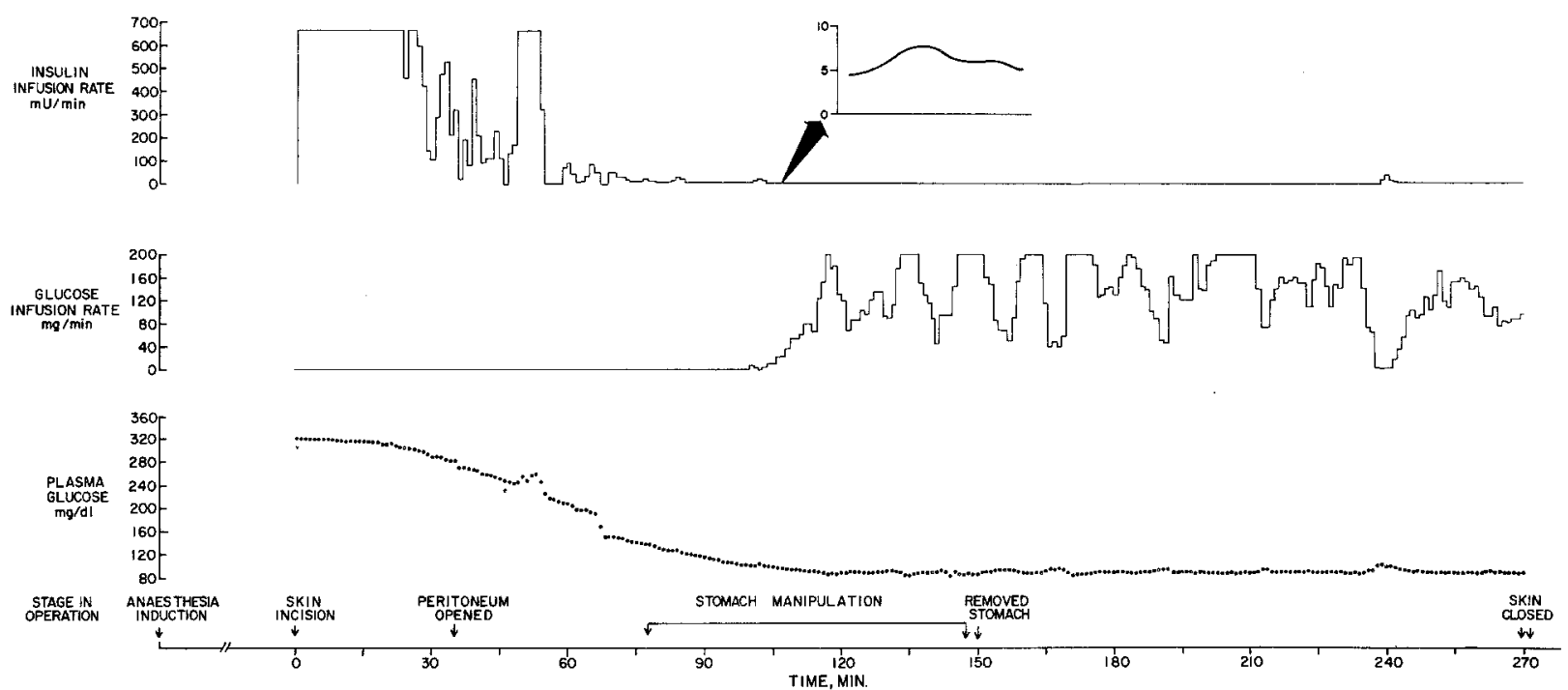

Fig. 1. Use of the GCIIS to control plasma glucose in patient DC-2. The inset for the insulin infusion rate indicates, in schematic form, that the insulin infusion rate is not zero in the latter times of the procedure but varies about $5 \mu \mathrm{U} / \mathrm{min}$

invaded by candida. The patient had an intravenous glucose infusion overnight prior to surgery and insulin was not given on the morning of operation. The initial plasma glucose concentration was $320 \mathrm{mg} / \mathrm{dl}$. The GCIIS gave insulin at a maximal rate $(680 \mathrm{mU} /$ $\min$ ) for 30 minutes and then a variably decreasing amount of insulin until the plasma glucose fell below $130 \mathrm{mg} / \mathrm{dl}$. At that point, the GCIIS started to infuse glucose at variable rates in addition to small amounts of insulin (usually less than $10 \mathrm{mU} / \mathrm{min}$ ) in order to keep the plasma glucose at approximately $100 \mathrm{mg} / \mathrm{dl}$.
The total amount of insulin infused in the 4.5 hour procedure was $30.4 \mathrm{U}$ of which $28.6 \mathrm{U}$ was given in the first hour. The total amount of glucose infused was $21.5 \mathrm{~g}$.

Patient DC-3 had a course quite similar to that shown in Figure 1. Patient DC-5 started with plasma glucose concentrations of less than $150 \mathrm{mg} / \mathrm{dl}$ and his course resembled the second half of Figure 1. Patients DC-1 and DC-4, though starting at plasma glucose levels similar to those shown in Figure 1, required a longer period of time (and more insulin) 
to achieve values of 130 and $150 \mathrm{mg} / \mathrm{dl}$ respectively at the end of their 4 hour procedures and thus received no glucose during their operation. Total amounts of glucose and insulin infused during surgery in these patients are shown in Table 2. In addition, the results of normal and diabetic patients infused with glucose and monitored without feedback during surgery are listed for comparison (Table 2).

\section{Plasma Glucose Levels in Normal and Diabetic Patients}

Mean plasma glucose values in each of the groups are shown in Figure 2. The GCIIS was able to achieve essentially the same plasma glucose level at 2 hours $(128 \pm 21 \mathrm{mg} / \mathrm{dl})$ as seen in the NS patients, despite a mean initial plasma glucose value significantly higher in the DC group than in the NS group (p < 0.02 ). DG patients had significantly higher mean plasma glucose levels during the first 2 hours of surgery $(247 \pm 36 \mathrm{mg} / \mathrm{dl})$ than NG patients $(185 \pm$ $16 \mathrm{mg} / \mathrm{dl} ; \mathrm{p}<0.05$ ), and both were significantly $(\mathrm{p}<$ $0.01)$ higher that the NS group $(106 \pm 4 \mathrm{mg} / \mathrm{dl})$. The degree of hyperglycaemia in the $\mathrm{NG}$ and $\mathrm{DG}$ patients was directly proportional to the glucose infusion rate during surgery $(r=0.78 ; p<0.01)$ (Figure 3 ).

\section{Insulin and C-Peptide Levels}

The GCIIS achieved the same plasma glucose at 2 hours as in the NS patients, but did so at the expense of marked peripheral hyperinsulinaemia (164 \pm 59 $\mu \mathrm{U} / \mathrm{ml}$ at 2 hours) (Table 3 ). The DC group appeared to have similar beta cell reserve to the $\mathrm{DG}$ patients, as basal mean C-peptide levels in both of these groups were similar (DG $=1.5 \pm 0.8 \mathrm{ng} / \mathrm{ml}$, $\mathrm{DC}=1.2 \pm 0.7 \mathrm{ng} / \mathrm{ml}$ ). NS patients had lower mean insulin levels during the first 2 hours than NG patients $(47.9 \pm 18.6 \mu \mathrm{U} / \mathrm{ml} ; \mathrm{p}<0.05)$, and this correlated with their lower initial plasma glucose levels $(\mathrm{r}=0.79 ; \mathrm{p}<0.01)$. The elevated plasma glucose levels seen in NG and DG patients, compared to NS patients, was not accompanied by a significant increase in mean C-peptide levels during the initial 2 hours of surgery in these groups (Table 3 ).

\section{Cortisol, Glucagon, Growth Hormone and Prolactin Levels in Normal and Diabetic Patients}

Cortisol levels increased over 3 hours within the NG and DG groups (Table 3; p $<0.01$ ), but there were no significant differences between the groups by analysis of variance. During the first 3 hours of surgery, there was no significant increase in glucagon,

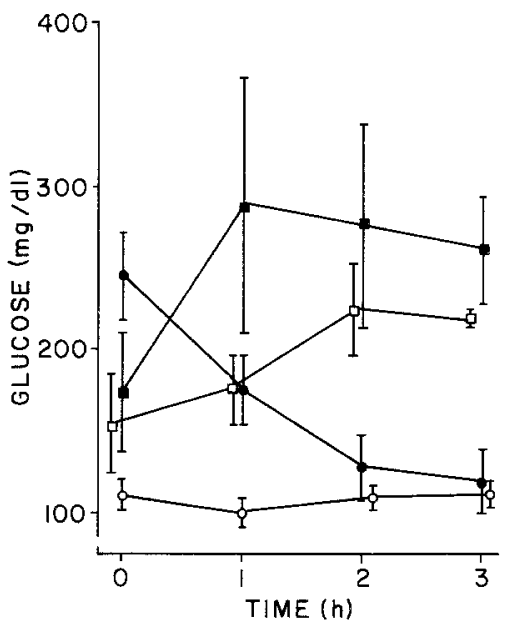

Fig. 2. Plasma glucose levels during surgery. All points are mean \pm SEM. Solid squares ( - ) - diabetics receiving intraoperative glucose (DG group). - Open squares ( $\square$ ) - normal subjects receiving intraoperative glucose (NG group). - Solid circles $(\bullet)$ - diabetics controlled by GCIIS (DC group). - Open circles (O) - normal subjects receiving intraoperative saline (NS group)

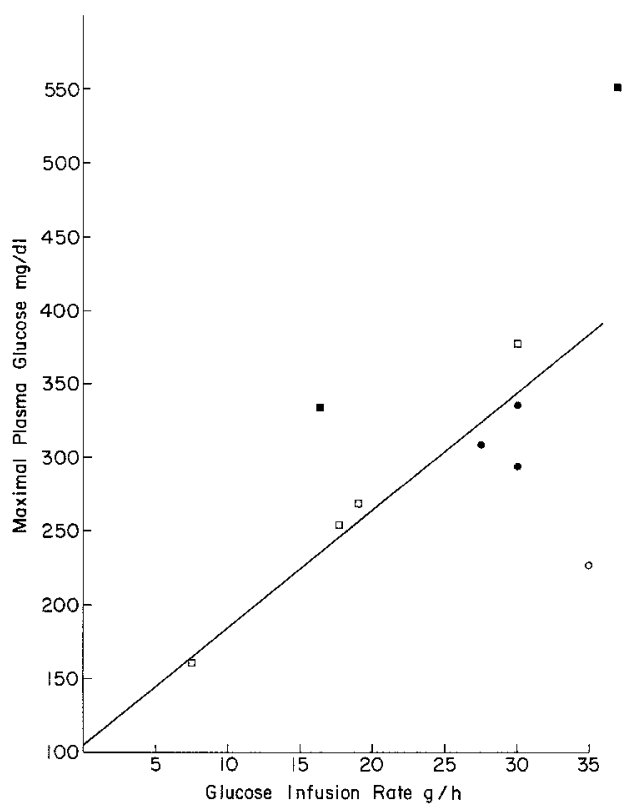

Fig. 3. Correlation of glucose infusion rate with maximal plasma glucose achieved during surgery. Average glucose infusion rates over the total period of surgery are used in 6 patients whose glucose was infused at a constant rate (squares). In the other 4 patients, the maximal plasma glucose was clearly related to a period of rapid glucose infusion, and this "peak" glucose infusion rate is used for those patients (circles). Open symbols represent normal subjects (NG group) and closed symbols diabetic subjects (DG group)

growth hormone or prolactin within each group (Table 3 ). In addition, there were no differences in peak, 2 hour, or peak minus basal levels of glucagon, growth hormone, or prolactin between the groups. 
Table 3. Hormonal concentrations during surgery (mean \pm SEM)

\begin{tabular}{|c|c|c|c|c|c|c|}
\hline $\begin{array}{l}\text { Patient group } \\
\text { and time }\end{array}$ & $\begin{array}{l}\text { Insulin } \\
(\mu \mathrm{U} / \mathrm{ml})\end{array}$ & $\begin{array}{l}\text { C-peptide } \\
\text { (ng/ml) }\end{array}$ & $\begin{array}{l}\text { Cortisol } \\
(\mu \mathrm{g} / \mathrm{dl})\end{array}$ & $\begin{array}{l}\text { Glucagon } \\
(\mathrm{pg} / \mathrm{ml})\end{array}$ & $\begin{array}{l}\text { Growth hormone } \\
(\mathrm{ng} / \mathrm{ml})\end{array}$ & $\begin{array}{l}\text { Prolactín } \\
\text { (ng/ml) }\end{array}$ \\
\hline \multicolumn{7}{|l|}{ Normal-saline } \\
\hline $0 \mathrm{~h}$ & $9.9 \pm \quad 4.2$ & $4.1 \pm 0.3$ & $16.4 \pm 6.8$ & $84 \pm 23$ & $2.0 \pm 1.4$ & $278 \pm 29$ \\
\hline $1 \mathrm{~h}$ & $9.3 \pm$ & $3.5 \pm 0.5$ & $28.9 \pm 2.1$ & $129 \pm 40$ & $2.1 \pm 0.8$ & $283 \pm 51$ \\
\hline $2 \mathrm{~h}$ & $10.8 \pm 5.2$ & $3.3 \pm 0.6$ & $35.5 \pm 6.7$ & $103 \pm 25$ & $7.2 \pm 6.1$ & $254 \pm 45$ \\
\hline $3 \mathrm{~h}$ & $11.8 \pm 10.1$ & $2.9 \pm 1.1$ & $34.2 \pm 9.7$ & $91 \pm 25$ & $2.9 \pm 2.0$ & $225 \pm 42$ \\
\hline \multicolumn{7}{|l|}{ Normal-glucose } \\
\hline $0 \mathrm{~h}$ & $37.9 \pm 23.0$ & $6.6 \pm 3.1$ & $15.7 \pm 4.7$ & $133 \pm 40$ & $2.0 \pm 1.7$ & $182 \pm 38$ \\
\hline $1 \mathrm{~h}$ & $72.4 \pm 47.2$ & $6.6 \pm 1.9$ & $24.1 \pm 10.7$ & $146 \pm 43$ & $2.2 \pm 1.3$ & $217 \pm 49$ \\
\hline $2 \mathrm{~h}$ & $28.7 \pm 12.2$ & $5.5 \pm 1.0$ & $35.8 \pm 10.1$ & $136 \pm 47$ & $18.4 \pm 13.6$ & $184 \pm 40$ \\
\hline $3 \mathrm{~h}$ & $22.3 \pm \quad 5.4$ & $5.5 \pm 1.8$ & $34.2 \pm 3.5$ & $146 \pm 59$ & $14.4 \pm 6.5$ & $179 \pm 44$ \\
\hline \multicolumn{7}{|c|}{ Diabetes-glucose } \\
\hline $0 \mathrm{~h}$ & $80.8 \pm 19.1$ & $1.5 \pm 0.8$ & $13.7 \pm 1.9$ & $188 \pm 62$ & $12.8 \pm 11.3$ & $179 \pm 55$ \\
\hline $1 \mathrm{~h}$ & $59.0 \pm 23.0$ & $1.7 \pm 0.8$ & $16.3 \pm 4.4$ & $174 \pm 59$ & $8.2 \pm 7.0$ & $187 \pm 54$ \\
\hline $2 \mathrm{~h}$ & $62.6 \pm 21.1$ & $1.0 \pm 0.5$ & $23.8 \pm 0.5$ & $180 \pm 51$ & $7.9 \pm 7.0$ & $171 \pm 48$ \\
\hline $3 \mathrm{~h}$ & $60.4 \pm 20.3$ & $0.7 \pm 0.3$ & $24.8 \pm 2.7$ & $185 \pm 58$ & $10.4 \pm 7.9$ & $158 \pm 41$ \\
\hline \multicolumn{7}{|l|}{ Diabetes-GCIIS } \\
\hline $0 \mathrm{~h}$ & $107.3 \pm 67.1$ & $1.2 \pm 0.7$ & $22.0 \pm 9.0$ & $122 \pm 40$ & $0.5 \pm 0.2$ & $145 \pm 43$ \\
\hline $1 \mathrm{~h}$ & $346.8 \pm 133.1$ & $1.0 \pm 0.3$ & $23.2 \pm 8.3$ & $114 \pm 43$ & $18.8 \pm 10.3$ & $173 \pm 28$ \\
\hline $2 \mathrm{~h}$ & $163.8 \pm 58.9$ & $0.8 \pm 0.3$ & $23.9 \pm 5.7$ & $117 \pm 53$ & $12.2 \pm 5.4$ & $150 \pm 10$ \\
\hline $3 \mathrm{~h}$ & $95.2 \pm 23.6$ & $0.7 \pm 0.3$ & $18.5 \pm 5.6$ & $78 \pm 23$ & $13.8 \pm 6.6$ & $158 \pm 11$ \\
\hline
\end{tabular}

\section{Discussion}

Hyperglycaemia associated with surgery is well known in nondiabetic patients [23-31], and may be more severe in patients with diabetes. In this study, normal patients receiving only saline intraoperatively showed a tendency to hyperglycaemia. This is compatible with the findings of Fletcher et al. [1] in diabetic subjects, who showed that significant hyperglycaemia did not develop in the absence of exogenous glucose. In normal and diabetic patients who received glucose intraoperatively, hyperglycaemia was clearly demonstrable at 2 hours with mean plasma glucose levels in NG and DG patients higher than in NS patients. As expected, the hyperglycaemia was even greater in diabetic patients receiving glucose than in normals treated similarly. An interesting finding, however, was that the degree of hyperglycaemia in normals and diabetics was clearly related to the rate of glucose infusion during surgery. This demonstrates the need to make informed decisions regarding rates of glucose infusion during surgical procedures in both normal and diabetic patients.

The hyperglycaemia of surgery has been associated with deficient insulin [23-25, 28-35] and Cpeptide responses [25] and possibly with insulin resistance $[35,36]$. Our results are in agreement with past investigations suggesting suppression of beta cell function during surgery. Thus, none of the groups $\mathrm{NS}, \mathrm{NG}$, or DG had a significant increase in insulin or C-peptide levels during the 2 hours of surgery. In addition, similar C-peptide levels in NS and NG patients suggest that hyperglycaemia in NG patients was due to an inability to metabolise exogenously infused glucose because of suppressed beta cell function. This impression is reinforced by the correlation of the glucose infusion rate with the degree of hyperglycaemia. The data also support the presence of insulin resistance, because patients controlled with the artificial beta cell required significant hyperinsulinaemia to achieve normalization of their plasma glucose level.

The suppression of insulin secretion and presence of insulin resistance intraoperatively are probably related to stimulation of the sympathetic nervous system and enhanced serum catecholamine response to stress, but the exact mechanisms involved are still debated $[23,25,26,30,32,34,35,37]$. The available data suggest that increased cortisol levels play a role in this state of insulin resistance $[26,28,35,38$, 39]. On the other hand, the absence in our study of any change in levels of glucagon and growth hormone during surgery suggests that these hormones have no intraoperative effect. However, as our initial samples were drawn at the time of skin incision, we cannot exclude the possibility that a small change in these hormone levels had already taken place. Most previous studies have also found no change, or even small decreases, in glucagon levels during surgery [29, 40, 41 , although one study showed an elevation of this hormone [31]. Growth hormone, however, has been 
found to be elevated during surgery in other studies [42-44].

In this study we achieved control of plasma glucose at the expense of hyperinsulinaemia. This phenomenon has been seen in other situations where the artificial beta cell has been used to control the plasma glucose of diabetic patients [45]. Further study is required to ascertain what effect, if any, this may have on the patient. Use of the GCIIS was found to be safe in that it did not cause hypo- or hyperglycaemia. It did not interfere with the surgeons or anaesthetists. It is of no added discomfort to the patient, requiring only one additional intravenous catheter placed after the patient is anaesthetised, and results in minimal $(2 \mathrm{ml} / \mathrm{h})$ additional blood loss during the procedure. Although we used a rapid method of measuring plasma glucose concentrations in order to calibrate and recheck the instrument, current instruments may be suitably calibrated with standard solutions, so a separate device is not necessary. We thus feel that anaesthesiologists, with minimal assistance, could operate the system in addition to their normal duties. In the future, therefore, this may provide valuable adjunctive support for the intraoperative management of some diabetic patients.

The importance of controlling hyperglycaemia during surgery must be considered, particularly with regard to whether or not the rigorous control made possible by the GCIIS has any advantage over the generally satisfactory control which results from other methods of insulin administration. While hyperglycaemia of any duration is potentially important in the pathogenesis of the late complications of diabetes [46], hyperglycaemia lasting only a few hours is of unknown quantitative significance. The real importance of these studies is in indicating that feedback control of insulin administration is feasible during the operative period and can potentially be extended to the pre- and postoperative periods to allow optimising the patient's metabolic and nutritional status for the entire perioperative course. Furthermore, the GCIIS has enabled us to study the hormonal responses to surgery in the diabetic patient while monitoring or controlling the plasma glucose. Thus, while use of the GCIIS may not offer any immediate advantages over other means of operative management (except, perhaps, in the very brittle patient or the patient with an insulinoma [47]), it holds promise of being an important investigative tool.

Acknowledgements. The authors would like to thank all members of the housestaff and faculty of the Departments of Surgery and Anaesthesiology at the University of Chicago Hospital without whose help this study could not have been completed. Particular thanks are given to Drs. Benson, Chief of Anaesthesiology, and
David Skinner, Chief of Surgery, who encouraged the undertaking of the study, and to Drs. DeMeester, Schonberg, Zarins, Enker, Ferguson, Stuart, and Shulberg who allowed their patients to participate in the study.

These studies were supported by grants from the USPHS (AM 19206, AM 19942), The National Cancer Institute (NCI CB 43976), the Diabetes Research and Training Center Grant (AM 20595), the Bertha and Henry Brownstein Foundation, and Miles Laboratories, Inc.

S. S. Schwartz is the recipient of the Bobby Clarke Fellowship of the Juvenile Diabetes Foundation, D. L. Horwitz is a recipient of a USPHS Research Career Development Award (AM 00181) and A. H. Rubenstein is an Established Investigator of the American Diabetes Association.

\section{References}

1. Fletcher, J., Langman, M. J.S., Kellock, T. D.: Effect of surgery on blood sugar levels in diabetes mellitus. Lancet 1965 II, $52-54$

2. Moore, F. D.: Metabolic care of the surgical patient, p. 643. Philadelphia: W. B. Saunders 1959

3. Rossini, A. A., Hare, J. W.: How to control the blood glucose level in the surgical diabetic patient. Arch. Surg. 111, 945-949 (1976)

4. Steinke, J.: Management of diabetes mellitus and surgery. N. Engl. J. Med. 282, 1472-1474 (1970)

5. Wheelock, Jr., F. C., Marble, A.: Surgery and diabetes. In: Joslin's diabetes mellitus. Marble, A., White, P., Bradiey, R. F., Krall, L. P. (Eds.), pp. 589-620. Philadelphia: Lea \& Febiger 1971

6. Galloway, J. A., Shuman, C. R.: Diabetes and surgery. Am. J. Med. 34, 177-191 (1963)

7. Bondy, P. K., Felig, P.: Disorders of carbohydrate metabolism. In: Duncan's diseases of metabolism. Bondy, P. K., Rosenberg, L. E. (Eds.), pp. 282-283. Philadelphia: W. B. Saunders 1974

8. Taitelman, U., Reece, E. A., Bessman, A. N.: Insulin in the management of the diabetic surgical patient; continuous intravenous infusion vs. subcutaneous administration. J. A.M. A. 237, 658-660 (1977)

9. Thomas, D. J. B., Platt, H. S., Smythe, P.; Assesment of continuous insulin infusion for the management of insulin dependent diabetics during and after surgery. Diabetologia 13 [Abstr.], 436 (1977)

10. Woodruff, R. E., Lewis, S. B., McLeskey, C. H., Steffenson, J. L., Matsenbaugh, S. L.: A reliable technique for strict intraoperative glucose control in insulin dependent diabetics. Diabetes 26 [Suppl. 1] [Abstr.], 423 (1977)

11. Galloway, J. A., Shuman, C. R.: Profile: Specific methods of management and response of diabetic patients to anesthesia in surgery. Int. Anesthesiol. Clin. 5, 437-466 (1967)

12. Pfeiffer, E. F., Thum, Ch., Clemens, A. H.: The artificial beta cell - a continuous control of blood sugar by external regulation of insulin infusion (glucose controlled insulin infusion system). Horm. Metab. Res. 487, 339-342 (1974)

13. Pfeiffer, E. F., Thum, Ch., Beischer, W., Clemens, A. H.: The artificial beta cell in clinical research. Diabetes 24 [Suppl. 2] [Abstr.], 404 (1975)

14. Clarke, W. C., Thomas, L., Santiago, J. V.: Clinical evaluation and preliminary studies on the use of an artificial beta cell in juvenile diabetes mellitus. J. Pediatr. 91, 590-596 (1977)

15. Morgan, C. R., Lazarow, A.: Immunoassay of insulin: two antibody systems. Plasma levels of normal, subdiabetic and diabetic rats. Diabetes 12, 115-126 (1963) 
16. Kuzuya, H., Blix, P. M., Horwitz, D. L., Rubenstein, A. H., Steiner, D. F., Binder, C., Faber, O. K.: Heterogeneity of circulating C-peptide. J. Clin. Endocrinol. Metab. 44, 952-962 (1977)

17. Kuzuya, H., Blix, P. M., Horwitz, D. L., Steiner, D. F., Rubenstein, A. H.: Determination of free and total insulin and C-peptide in insulin treated diabetics. Diabetes 26, 22-29 (1977)

18. Kuku, S. F., Zeidler, A., Emmanouel, D. S., Katz, A. I., Rubenstein, A. H., Levin, N.W., Tello, A.: Heterogeneity of plasma glucagon: patterns in chronic renal failure and diabetes. J. Clin. Endocrinol. Metab. 42, 173-176 (1976)

19. Odell, W. D., Rayford, P. L., Ross, G. T.: Simplified, partially automated method for radioimmunoassay of human thyroidstimulating, growth, luteinizing, and follicle stimulating hormones. J. Lab. Clin. Med. 70, 973-980 (1967)

20. Murphy, B.E. P.: Some studies of the protein binding of steroids and their application to the routine micro and ultramicro measurement of various steroids in body fluids by competitive protein binding radioassay. J. Clin. Endocrinol. Metab. 27, 973-990 (1967)

21. Fang, V. S., Armstrong, J., Worsley, I. G.: Interbatch quality differences of purified human prolactin. Clin. Chem. 24, 941-943 (1978)

22. Stein, M. W.: D-Glucose: Determination with hexokinase and glucose-6-phosphate dehydrogenase. In: Methods of enzymatic analysis. Bergmeyer, H. U. (Ed.), pp. 117-123. New York: Academic Press 1963

23. Allison, S. P., Tomlin, P. J., Chamberlain, M. J.: Some effects of anaesthesia and surgery on carbohydrate and fat metabolism. Br. J. Anaesth. 41, 588-592 (1969)

24. Brandt, M. R., Kehlet, H., Binder, C., Hager C., McNeilly, A. S.: Effect of epidural analgesia on the glycoregulatory endocrine response to surgery. Clin. Endocrinol. (Oxf.) 5, 107-114 (1976)

25. Brandt, M. R., Kehlet, H., Faber, O., Binder, C.: C-Peptide and insulin during blockade of the hyperglycemic response to surgery by epidural analgesia. Clin. Endocrinol. (Oxf.) 6, $167-170$ (1977)

26. Bromage, P. R., Shibata, H. R., Willoughby, H. W.: Influence of prolonged epidural blockade on blood sugar and cortisol responses to operations upon the upper part of the abdomen and the thorax. Surg. Gynecol. Obstet. 132, 1051-1056 (1971)

27. Clarke, R. S. J.: Hyperglycaemic response to different types of surgery and anaesthesia. Br. J. Anaesth. 42, 45-52 (1970)

28. Clarke, R. S. J., Johnston, H., Sheridan, B.: The influence of anaesthesia and surgery on plasma, cortisol, insulin and free fatty acids. Br. J. Anaesth. 42, 295-299 (1970)

29. Giddings, A. E. B., O'Conner, K. J., Rowlands, B. J., Mangnall, D., Clark, R. G.: The relationship of plasma glucagon to the hyperglycaemia and hyperinsulinaemia of surgical operation. Br. J. Surg. 63, 612-616 (1976)

30. Nakao, K., Miyata, M.: The influence of phentolamine, an adrenergic blocking agent, on insulin secretion during surgery. Eur. J. Clin. Invest. 4, 41-45 (1977)

31. Russell, R. C. G., Walker, C. J., Bloom, S. R.: Hyperglucagonaemia in the surgical patient. Br. Med. J. $1975 \mathrm{I}$, $10-12$
32. Aarimaa, M., Slatis, P., Haapaniemi, L., Jeglinsky, B.: Glucose tolerance and insulin response during and after elective skeletal surgery. Ann. Surg. 179, 926-929 (1974)

33. Alant, O., Pulay, I., Esztergalyos, J., Bodnar, A.: The effect of surgery on carbohydrate metabolism. Acta Chir. Acad. Sci. Hung. 17, 1-10 (1976)

34. Halter, J. B., Pflug, A. E., Porte, Jr., D.: Adrenergic and nonadrenergic effects of anaesthesia and surgical stress on insulin secretion in man. Clin. Res. 26 [Abstr.], 158 (1978)

35. Wright, P. D., Henderson, K., Johnston, I. D. A.: Glucose utilization and insulin secretion during surgery in man. Br. J. Surg. 61, 5-8 (1974)

36. Giddings, A. E. B.: The control of plasma glucose in the surgical patient. Br. J. Surg. 61, 787-792 (1974)

37. Nikki, P., Takki, S., Tammisto, T., Jaatela, A.: Effect of operative stress on plasma catecholamine levels. Ann. Clin. Res. 4, $146-151$ (1972)

38. Plumpton, F. S., Besser, G. M., Cole, P. V.: Corticosteroid treatment and surgery: an investigation of the indications for steroid coverage. Anaesthesia 24, 3-11 (1969)

39. Nistrup-Madsen, S., Engquist, A., Badawi, I., Kehlet, H.: Cyclic AMP, glucose and cortisol in plasma during surgery. Horm. Metab. Res. 8, 483-485 (1976)

40. Lindsay, A., Santensanio, F., Braaten, J., Faloona, G. R., Unger, R. H.: Pancreatic alpha cell function in trauma. J. A. M. A. 227, 757-761 (1974)

41. Miyata, M., Yamamoto, T., Nakao, K.: Suppression of glucagon secretion during surgery. Horm. Metab. Res. 8, 239-240 (1976)

42. Glick, S. M., Roth, J., Yalow, R. S., Berson, S. A.: The regulation of growth hormone secretion. Recent Prog. Horm. Res. 21, 241-270 (1965)

43. Russell, R. C. G., Ellis, B., Spargo, P., Dudley, H. A. F.: The relationship between insulin and growth hormone before, during and after minor surgery. Br. J. Surg. 63 [Abstr.], 666-667 (1973)

44. Wright, P. D., Johnston, I. D. A.: The effect of surgical operation on growth hormone levels in plasma. Surgery 77, 479-486 (1975)

45. Horwitz, D. L., Gonen, B., Zeidler, A., Langer, B., Rodman, D.: An artificial beta cell for control of diabetes: Comparison of glucose and free insulin levels with those achieved by subcutaneous insulin insulin. Diabetes 26 [Suppl. 1] [Abstr.], 376 (1977)

46. Cahill, Jr., G. F., Etzwiler, D. D., Freinkel, N.: "Control" and diabetes. N. Engl. J. Med. 294, 1004-1005 (1976)

47. Kudlow, J. W., Albisser, A. M., Ongel, A., Langer, B., Yip, C. C., Zinman, B., Stokes, E.: Insulinoma resection facilitated by artificial endocrine pancreas. Diabetes 27, 774-777 (1978)

Received: June 12, 1978,

and in revised form: October 10, 1978

David L. Horwitz, M. D., Ph. D.

The University of Chicago

Department of Medicine

950 East 59th Street

Chicago, IL 60637

USA 